\title{
Urethral Infection
}

National Cancer Institute

\section{Source}

National Cancer Institute. Urethral Infection. NCI Thesaurus. Code C78671.

A bacterial, viral, or fungal infectious process affecting the urethra. 